\title{
Editorial: The Role of the Plasminogen Activating System in Neurobiology
}

\author{
Robert L. Medcalf ${ }^{1 *}$ and Daniel A. Lawrence ${ }^{2}$ \\ 'Molecular Neurotrauma and Haemostasis, Australian Centre for Blood Diseases, Monash University, Melbourne, VIC, \\ Australia, ${ }^{2}$ Division of Cardiovascular Medicine, Department of Internal Medicine, University of Michigan Medical School, \\ Ann Arbor, MI, USA
}

Keywords: plasminogen, plasminogen activators, blood brain barrier, ischaemic stroke, traumatic brain injury (TBI), neurotoxicity, neuroprotection

\section{The Editorial on the Research Topic}

\section{The Role of the Plasminogen Activating System in Neurobiology}

The plasminogen activating system has been well-appreciated for its roles in fibrinolysis and metastatic cancer for over 30 years. These observations lead to the clinical development of the key plasminogen activators, namely urokinase ( $\mathrm{u}-\mathrm{PA}$ ), and tissue-type plasminogen activator ( $\mathrm{t}-\mathrm{PA}$ ) as thrombolytic agents, initially for myocardial infarction in the mid-1980's, and a decade later for use in patients with ischaemic stroke following the approval of tPA (Ninds, 1995). Similarly various attempts were made to modulate cell surface plasminogen activation in an effort to reduce metastatic spread with varying success, although various components of this system have become biomarkers for some malignancies (McMahon and Kwaan, 2015).

While many laboratories continue to work in these classical areas, and with due reason, a growing list of publications dating from the early 1980's revealed that the main components of the plasminogen activating system were expressed in almost all cell types and were regulated

OPEN ACCESS

Edited by:

Christian Hansel,

University of Chicago, USA

Reviewed by:

Sidney Strickland,

Rockefeller University, USA

${ }^{*}$ Correspondence:

Robert L. Medcalf

robert.medcalf@monash.edu

Received: 01 August 2016

Accepted: 09 September 2016

Published: 04 October 2016

Citation:

Medcalf RL and Lawrence DA (2016) Editorial: The Role of the Plasminogen

Activating System in Neurobiology.

Front. Cell. Neurosci. 10:222.

doi: 10.3389/fncel.2016.00222 by agonists linked to almost all signal transduction pathways identified (Medcalf, 2007). While these reports were consistent with a broadening role of the plasminogen activating system in physiology, other findings also from the early 1980's reported strong expression of components of the plasminogen activating system in the central nervous system (Krystosek and Seeds, 1981; Soreq and Miskin, 1981). While these were largely descriptive studies, and without any clear connection to conventional fibrinolysis or metastatic cancer, speculation arose as to the role of the plasminogen activating system in the CNS (Yepes and Lawrence, 2004), particularly given the fact that the normal brain is devoid of fibrin. A decade or so later, CNS focused reports of activity dependent expression of t-PA in the brain added substantial fuel to notion of a critical role for t-PA in normal brain function, with increases in t-PA gene expression in the CNS correlated with long term potentiation (Qian et al., 1993; Huang et al., 1996); and motor learning (Seeds et al., 1995). Soon after, reports using t-PA deficient mice provided evidence for surprising neurotoxic effects of t-PA where t-PA, via plasmin was shown to be necessary to facilitate glutamate-mediated toxicity in vivo (Chen and Strickland, 1997). These reports were published at about the same time that t-PA was approved for therapeutic use in patients with ischemic stroke and raised concerns with the clinical use of t-PA given the fact t-PA administration in ischemic stroke was not risk-free.

It soon became apparent that t-PA was influencing numerous other aspects of brain function including modulation of memory (Huang et al., 1996) and learning (Seeds et al., 2003) and the response to drugs of addiction (Pawlak et al., 2005; Bahi and Dreyer, 2008; Maiya et al., 2009). Another landmark discovery made in the early 2000's reported a potent effect of t-PA at promoting 
$\mathrm{BBB}$ disruption in rodent models of cerebral ischemia (Yepes et al., 2003), an effect that has since been documented in a subset of human stroke patients who receive thrombolysis (Kidwell et al., 2008). This further added to the debate of t-PA as a safe thrombolytic in patients with ischaemic stroke. The enhancing effect of $\mathrm{t}-\mathrm{PA}$ on $\mathrm{BBB}$ permeability not only directed many laboratories to uncover the mechanism behind this ( $\mathrm{Su}$ et al., 2008; Niego et al., 2012), but also raised interest in other areas of brain pathology where $\mathrm{BBB}$ integrity was compromised, namely in traumatic brain injury (TBI, Mori et al., 2001). Initial research into the role of t-PA at influencing outcome following TBI resulted in a number of publications supporting the notion that brain-derived t-PA, as opposed to exogenous t-PA (as in ischemic stroke), was also promoting BBB permeability and subsequent deleterious outcome following TBI (Sashindranath et al., 2012; $\mathrm{Su}$ et al.). It soon became apparent that t-PA was indeed a major modulator of BBB permeability (Niego and Medcalf, 2014), even under non-ischemic or traumatic conditions (Fredriksson et al., 2016).

With the realization of these various roles of $\mathrm{t}-\mathrm{PA}$ in the CNS, questions arose as to how t-PA was implementing these effects and how it was being regulated. t-PA modulating agents i.e., neuroserpin (Lebeurrier et al., 2005), critical signaling systems i.e., tyrosine kinase (Su et al., 2008), and Rho kinase pathways (Niego et al., 2012), and receptors i.e., LRP-1 (Yepes et al., 2003; Samson et al., 2008), and PDGFR $\alpha$ (Fredriksson et al., 2004) in the CNS were later identified by various groups to participate in this new frontier of plasminogen activation biology. Although these findings pushed the field further, controversy also arose. Conflicting reports on how t-PA promoted neurotoxicity (Nicole et al., 2001; Matys and Strickland, 2003; Samson et al., 2008), or its opposite effect (i.e., neuroprotection) via non-proteolytic means (Kim et al., 1999), or proteolytically at low concentrations (Echeverry et al., 2010; Wu et al., 2012) continued to pepper the literature, particularly in recent years (Yepes). The diverse reach of the plasminogen activators in the brain also posed the question as to whether there was a common mechanistic element behind these various, seemingly unrelated events (Fredriksson et al., 2016).

This themed issue of Frontiers in Cellular Neuroscience entitled "The role of the plasminogen activating system in

\section{REFERENCES}

Bahi, A., and Dreyer, J. L. (2008). Overexpression of plasminogen activators in the nucleus accumbens enhances cocaine-, amphetamine- and morphineinduced reward and behavioral sensitization. Genes Brain Behav. 7, 244-256. doi: 10.1111/j.1601-183X.2007.00346.x

Chen, Z. L., and Strickland, S. (1997). Neuronal death in the hippocampus is promoted by plasmin-catalyzed degradation of laminin. Cell 91, 917-925. doi: 10.1016/S0092-8674(00)80483-3

Echeverry, R., Wu, J., Haile, W. B., Guzman, J., and Yepes, M. (2010). Tissue-type plasminogen activator is a neuroprotectant in the mouse hippocampus. J. Clin. Invest. 120, 2194-2205. doi: 10.1172/JCI41722

Fredriksson, L., Lawrence, D. A., and Medcalf, R. L. (2016). t-PA modulation of the blood-brain barrier: a unifying explanation for the pleiotropic effects of tPA in
Neurobiology" contains 12 contributions from key scientists in this field that includes topics ranging from basic neurobiology, ischaemic stroke, and TBI. Data is presented to implicate t-PA in neurovascular development, how parallel protease systems (i.e., the MMPs) may participate in some aspects of t-PA's effects in the CNS, novel approaches to attenuate t-PA mediated BBB permeability in TBI, and new insights into the biology of the major brain t-PA inhibitor, neuroserpin. We have endeavored to cover areas of controversy, particularly in relation to the purported roles of t-PA at promoting both neurotoxicity and neuroprotection while at the same time include state-of-the-art reviews, including the insights as to how the coagulation and the fibrinolytic systems can modulate the neurovascular unit and how this can in turn have an impact on the immune response.

This themed issue also includes clinical and basic science perspectives which are likely to seed further innovation to future research in this field. At the time of writing this Editorial, these 12 articles have amassed over 15,000 article views and nearly 3000 downloads within $\sim 14$ months since publication, providing clear evidence that this particular topic continues to be vibrant, appealing, and important. The relatively recent entry of the plasminogen activator into the field of neurobiology has certainly been an eye-opener. As technology ultimately advances, it is almost certain that the subsequent years will not only uncover novel mechanistic insights into the how the plasminogen activating system functions in the CNS, but it will also uncover important roles for this enzyme system in other key areas of neurobiology.

\section{AUTHOR CONTRIBUTIONS}

All authors listed, have made substantial, direct and intellectual contribution to the work, and approved it for publication.

\section{FUNDING}

This work was funded in part by funds awarded to RM from the National Health and Medical Research Council of Australia, grant numbers 1045755 and 1045756, and to DL from the National Institutes of Health grant numbers HL055374 and NS079639. the CNS. Semin. Thromb. Hemost. doi: 10.1055/s-0036-1586229. [Epub ahead of print].

Fredriksson, L., Li, H., Fieber, C., Li, X., and Eriksson, U. (2004). Tissue plasminogen activator is a potent activator of PDGF-CC. EMBO J. 23, 3793-3802. doi: 10.1038/sj.emboj.7600397

Huang, Y. Y., Bach, M. E., Lipp, H. P., Zhuo, M., Wolfer, D. P., Hawkins, R. D., et al. (1996). Mice lacking the gene encoding tissue-type plasminogen activator show a selective interference with late-phase long-term potentiation in both Schaffer collateral and mossy fiber pathways. Proc. Natl. Acad. Sci. U.S.A. 93, 8699-8704. doi: 10.1073/pnas.93.16.8699

Kidwell, C. S., Latour, L., Saver, J. L., Alger, J. R., Starkman, S., Duckwiler, G., et al. (2008). Thrombolytic toxicity: blood brain barrier disruption in human ischemic stroke. Cerebrovasc. Dis. 25, 338-343. doi: 10.1159/000 118379 
Kim, Y. H., Park, J. H., Hong, S. H., and Koh, J. Y. (1999). Nonproteolytic neuroprotection by human recombinant tissue plasminogen activator. Science 284, 647-650. doi: 10.1126/science.284.5414.647

Krystosek, A., and Seeds, N. W. (1981). Plasminogen activator secretion by granule neurons in cultures of developing cerebellum. Proc. Natl. Acad. Sci. U.S.A. 78, 7810-7814. doi: 10.1073/pnas.78.12.7810

Lebeurrier, N., Liot, G., Lopez-Atalaya, J. P., Orset, C., Fernandez-Monreal, M., Sonderegger, P., et al. (2005). The brain-specific tissue-type plasminogen activator inhibitor, neuroserpin, protects neurons against excitotoxicity both in vitro and in vivo. Mol. Cell. Neurosci. 30, 552-558. doi: 10.1016/j.mcn.2005.09.005

Maiya, R., Zhou, Y., Norris, E. H., Kreek, M. J., and Strickland, S. (2009). Tissue plasminogen activator modulates the cellular and behavioral response to cocaine. Proc. Natl. Acad. Sci. U.S.A. 106, 1983-1988. doi: 10.1073/pnas.0812491106

Matys, T., and Strickland, S. (2003). Tissue plasminogen activator and NMDA receptor cleavage. Nat. Med. 9, 371-372. doi: 10.1038/nm0403-371

McMahon, B. J., and Kwaan, H. C. (2015). Components of the plasminogenplasmin system as biologic markers for cancer. Adv. Exp. Med. Biol. 867, 145-156. doi: 10.1007/978-94-017-7215-0_10

Medcalf, R. L. (2007). Fibrinolysis, inflammation, and regulation of the plasminogen activating system. J. Thromb. Haemost. 5(Suppl. 1), 132-142. doi: 10.1111/j.1538-7836.2007.02464.X

Mori, T., Wang, X., Kline, A. E., Siao, C. J., Dixon, C. E., Tsirka, S. E., et al. (2001). Reduced cortical injury and edema in tissue plasminogen activator knockout mice after brain trauma. Neuroreport 12, 4117-4120. doi: 10.1097/00001756200112210-00051

Nicole, O., Docagne, F., Ali, C., Margaill, I., Carmeliet, P., Mackenzie, E. T., et al. (2001). The proteolytic activity of tissue-plasminogen activator enhances NMDA receptor-mediated signaling. Nat. Med. 7, 59-64. doi: 10.1038/83358

Niego, B., Freeman, R., Puschmann, T. B., Turnley, A. M., and Medcalf, R. L. (2012). t-PA-specific modulation of a human blood-brain barrier model involves plasmin-mediated activation of the Rho kinase pathway in astrocytes. Blood 119, 4752-4761. doi: 10.1182/blood-2011-07-369512

Niego, B., and Medcalf, R. L. (2014). Plasmin-dependent modulation of the bloodbrain barrier: a major consideration during tPA-induced thrombolysis? J. Cereb. Blood Flow Metab. 34, 1283-1296. doi: 10.1038/jcbfm.2014.99

Ninds (1995). Tissue plasminogen activator for acute ischemic stroke. The national institute of neurological disorders and stroke rt-PA stroke study group. N. Engl. J. Med. 333, 1581-1587.

Pawlak, R., Melchor, J. P., Matys, T., Skrzypiec, A. E., and Strickland, S. (2005). Ethanol-withdrawal seizures are controlled by tissue plasminogen activator via modulation of NR2B-containing NMDA receptors. Proc. Natl. Acad. Sci. U.S.A. 102, 443-448. doi: 10.1073/pnas.0406454102

Qian, Z., Gilbert, M. E., Colicos, M. A., Kandel, E. R., and Kuhl, D. (1993). Tissue-plasminogen activator is induced as an immediate-early gene during seizure, kindling and long-term potentiation. Nature 361, 453-457. doi: $10.1038 / 361453 \mathrm{a} 0$

Samson, A. L., Nevin, S. T., Croucher, D., Niego, B., Daniel, P. B., Weiss, T. W., et al. (2008). Tissue-type plasminogen activator requires a co-receptor to enhance NMDA receptor function. J. Neurochem. 107, 1091-1101. doi: 10.1111/j.1471-4159.2008.05687.x

Sashindranath, M., Sales, E., Daglas, M., Freeman, R., Samson, A. L., Cops, E. J., et al. (2012). The tissue-type plasminogen activator-plasminogen activator inhibitor 1 complex promotes neurovascular injury in brain trauma: evidence from mice and humans. Brain 135, 3251-3264. doi: 10.1093/brain/ aws 178

Seeds, N. W., Basham, M. E., and Ferguson, J. E. (2003). Absence of tissue plasminogen activator gene or activity impairs mouse cerebellar motor learning. J. Neurosci. 23, 7368-7375.

Seeds, N. W., Williams, B. L., and Bickford, P. C. (1995). Tissue plasminogen activator induction in Purkinje neurons after cerebellar motor learning. Science 270, 1992-1994. doi: 10.1126/science.270.5244.1992

Soreq, H., and Miskin, R. (1981). Plasminogen activator in the rodent brain. Brain Res. 216, 361-374. doi: 10.1016/0006-8993(81)90138-4

Su, E. J., Fredriksson, L., Geyer, M., Folestad, E., Cale, J., Andrae, J., et al. (2008). Activation of PDGF-CC by tissue plasminogen activator impairs bloodbrain barrier integrity during ischemic stroke. Nat. Med. 14, 731-737. doi: $10.1038 / \mathrm{nm} 1787$

Wu, F., Wu, J., Nicholson, A. D., Echeverry, R., Haile, W. B., Catano, M., et al. (2012). Tissue-type plasminogen activator regulates the neuronal uptake of glucose in the ischemic brain. J. Neurosci. 32, 9848-9858. doi: 10.1523/JNEUROSCI.1241-12.2012

Yepes, M., and Lawrence, D. A. (2004). New functions for an old enzyme: nonhemostatic roles for tissue-type plasminogen activator in the central nervous system. Exp. Biol. Med. (Maywood). 229, 1097-1104.

Yepes, M., Sandkvist, M., Moore, E. G., Bugge, T. H., Strickland, D. K., and Lawrence, D. A. (2003). Tissue-type plasminogen activator induces opening of the blood-brain barrier via the LDL receptor-related protein. J. Clin. Invest. 112, 1533-1540. doi: 10.1172/JCI200319212

Conflict of Interest Statement: The authors declare that the research was conducted in the absence of any commercial or financial relationships that could be construed as a potential conflict of interest.

Copyright (C) 2016 Medcalf and Lawrence. This is an open-access article distributed under the terms of the Creative Commons Attribution License (CC BY). The use, distribution or reproduction in other forums is permitted, provided the original author(s) or licensor are credited and that the original publication in this journal is cited, in accordance with accepted academic practice. No use, distribution or reproduction is permitted which does not comply with these terms. 